\title{
The Protection of Rights to Healthcare for People with Mental Illness in Stocks in the Era of National Health Insurance
}

\author{
Endang Sutrisno* \\ Department of Law \\ Universitas Swadaya Gunung Jati \\ Cirebon, Indonesia \\ *endangsutrisno94@gmail.com
}

\author{
Junaedi Junaedi \\ Department of Accountancy \\ Universitas Swadaya Gunung Jati \\ Cirebon, Indonesia
}

\author{
Nina Nur Ainy Syarief \\ Universitas Swadaya Gunung Jati \\ Cirebon, Indonesia
}

\begin{abstract}
Protection for People with Mental Illness (PMI) in stocks is by releasing them while at the same time granting them rights to healthcare so that PMI can find their way to recovery and are expected to return to the community. This research aims to describe the policies regarding stocked People with Mental Illness (PMI) in the era of National Health Insurance (NHI), the rights to healthcare fulfilled to protect stocked PMI in Majalengka regency. This research is non-doctrinal, while employing social legal studies, qualitative studies, analyzed using triangulation method, and presented in a descriptive approach. The findings show that policies of central government and regional government of West Java have included rights to healthcare for PMI with a new orientation in NHI era, that is as a social protection in health, especially for the poor; secondly, rights to healthcare for stocked PMI are not yet implemented in an integrated, comprehensive, coordinated, and sustainable way, as it is shown in the absence of inpatient facilities for PMI in the level of regency as well as the lack of awareness from the relatives of PMI of the importance of healthcare for PMI.
\end{abstract}

Keywords: rights to healthcare, people with mental illness, stocks, National Health Insurance

\section{INTRODUCTION}

Mental health issue has become a global concern, including in Indonesia. According to WHO, in 2016 there are approximately 35 million people with depression, 60 million people with bipolar disorder, 21 million people with schizophrenia, and 47.5 million people with dementia. In Indonesia, supported by various biological, psychological, and social factors, the number of mental issue cases seem to increase and it has an impact in the increase of state burden and the decline of long-term human productivity. According to Basic Health Research (RIKESDAS) approximation in 2013, it was estimated that there were 72 thousand mental health cases with $14.3 \%$ of those were estimated in stocks, or about 10,010 cases. According to data obtained by the Psychiatric Hospital of West Java, it is acknowledged that in 2017 there were 149 reported cases of stocked PMI. The actual data is beyond the recorded data, like an iceberg phenomenon. Cases of stocked PMI handled by Psychiatric Hospitals from 2011 to 2017 were 335 cases or $3.35 \%$ [1].

The prohibition of using stocks in the legal and medical points of view is based on solid grounds. De jure, using stocks violates a number of regulations; and medically, stocks stimulates more issues with PMI's physical problem. Protection for PMI in stocks covers two matters, which are unlocking stocks and granting rights to healthcare. Rights to healthcare for People with Mental Illness (PMI) is a basic right as a protection for people with mental disorders. By granting those rights to healthcare, it is expected that they can recover and return to the society and get more rights. Rights to healthcare for PMI should be implemented in an integrated, comprehensive, sustainable, and coordinated way throughout the life cycle of PMI. Rights to healthcare for stocked PMI is closely related to a curative attempt that needs an immediate treatment to the emergency of mental health.

Currently, there is a complicated issue with the practice of using stocks regarding facilities and infrastructure as well as healthcare procedures for PMI, not to mention social issues resulting in many obstacles that prevent PMI from getting proper protection and rights to healthcare [2]. A new paradigm in the National Health Insurance (NHI) era in healthcare that is oriented toward PMI recovery and demands a restructuration in inclusive mental healthcare in regency level that is multidisciplinary and multisector supported by the society. Therefore, this research is intended to describe the policies regarding stocked People with Mental Illness (PMI) in the era of National Health Insurance (NHI) and the rights to healthcare fulfilled to protect stocked PMI in Majalengka regency. 


\section{METHODS}

This study involves paradigm critical, a critical process to reveal the issue of legal protection of rights to healthcare for stocked people with mental illness that is happening as a reality in society, in relation to healthcare orientation in HNI era. This study attempts to raise new awareness to see the actual reality of putting PMI in stocks. This study employs socio legal studies approach.

This study is qualitative in nature, emphasizing the reality that is socially founded in terms of protection of rights to healthcare for stocked people with mental illness and its close relation between researcher and object of study. Data presented in this study is primary data obtained through observations and interviews, ad secondary data in form of regulations, books, journals, and others that support this study.

The population of the research is people with mental illness (PMA) in Majalangka Regency. To get the data, several people are taken from the population. The reason is to draw a maximum conclusion. Data analysis is done using triangulation method using documents, interview, and observation. Qualitative analysis process is elucidated in three steps, which are reduction, narrative data presentation, and drawing conclusion and verification.

\section{RESULTS AND DISCUSSION}

The data gained indicate that the right to get health protection for people with mental illness is still very low. This is due to the ignorant attitude toward their environment including the people with mental illness. Meanwhile in article 1 paragraph (3) Law Number 18 Year 2014 regarding Mental Health and article 1 paragraph (10) Regional Regulation of West Java Province Number 5 Year 2018, it is stated that: People with Mental Illness, later addressed as PMI, are people who have disorders in thoughts, behaviors, and sentiments that are manifested in a number of symptoms and/or a meaningful change in behavior that is potential to cause suffering and hindrance in playing a role as a human being. Psychosis is a severe mental disorder which is marked by detachment from reality, suspicion, hallucination, and often random thinking pattern. Another classification with multiaxis system based on ICD-10 and DSM-IV-TR using similar but not identical main diagnosis category mentions 13 categories, including Schizophrenia. Therefore, as a social creature they are supposed to care about their environment like people with mental illness.

Rights to healthcare according to Law Number 18 Year 2014 regarding Mental Health include rights to get mental healthcare in accessible healthcare facilities, healthcare according to standards, and insurance to the availability of psychofarmaca medication according to needs. Meanwhile, according to Article 3 Law Number 18 Year 2014 regarding Mental Health, it is stated that Mental Health Aid is provided to give protection and guarantee mental healthcare for PMI and People with Mental Issue to get their rights as the citizens of Indonesia.

Policies regulating PMI in Regional Regulations of West Java Province haven given an example of modern legal policies in a broad term. David Easton defines policies as the authoritative allocation of values for the whole society. The making of policies regulating mental health roots from acknowledgment of mental health issues within the society that needs to be regulated by policies. Acknowledgment of mental health issues presents a social issue that needs involvement of the government with following serious public treatment in order. Legal norms comes in private sphere. It is as the argument that the law does not work in a vacuum. For this reason social problems must be handled extraordinarily by law and must work in an extraordinary way [3]. Law enforcement refers to implementing the textual of legal norms in the social realities of society. The content of the substance of the norm is hoped to be clarified through legal behavior so that questions about legal awareness, legal compliance, legal feelings, and legal attitude will be more prominent [4].

Regional Regulations and other sub-regulations in regency level are required so that the practice of mental health can be optimally implemented. Currently, there is no regional regulation that deals with mental health or PMI in Majalengka Regency. Moreover, regional regulation is needed as a form of arrangement through legal regulation that is absolute in improving the role of local government in regional autonomy.

Policies regulating rights to healthcare for PMI in Majalengka Regency are written in Healthcare of Division in Public Health Office of Majalengka that regulates Facilitation of Handling Mental Disorder Cases. The emerging problem is the time, considering facilitation of handling mental disorder cases requires a relatively long time due to waiting for confirmation regarding wards due to limited facilities at Psychiatric Hospital in West Java as the main reference in fulfilling rights to healthcare for stocked PMI.

The lacking readiness of Regional General Hospital in accommodating inpatients of mental health issues is closely related to the resources that cover human resources and facilities/infrastructure to accommodate mental healthcare that is significantly important because it involves safety and security of all parties, both PMI or hospital employees and officials.

Mental disorders are included into paid expenses in National Health Insurance (NHI) - Indonesian Health Card (KIS). Regulation of Minister of Health Number 76 Year 2016 regarding Guideline of Indonesian Case Base Group (INA$\mathrm{CBG})$ in the implementation of National Health Insurance (NHI) mentions that Mental Health and Behavioral Groups (F) are classified to disease in which expenses are paid by the Indonesian National Health Insurance System (BPJS).

There were 11 stocked PMI in 2017 from Majalengka regency come from poor and underprivileged families. All PMI are registered as participants of BPJS and BPJS/KIS holders. BPJS/KIS cards were obtained from Contribution Recipients (PBI) whose tuitions are paid by the government and others are poor and underprivileged citizens who obtained BPJS/KIS through recommendation from Social Services. They later become PBI whose premiums are paid by the local government of individual participations. 
BPJS/KIS card owned by PMI is used during emergency of mental healthcare at Psychiatric Hospitals in West Java or other hospitals that provide inpatient treatments for PMI and our patient treatment in recommended healthcare facilities that are hospitals.

Social empowerment and rehabilitation by Social Welfare Institution is done after PMI finish healthcare and in a fullyrecovered state, and it is confirmed that PMI had regular treatment. Social Services of Majalengka Regency, in terms of social empowerment and rehabilitation towards PMI, cooperate with Private Social Welfare Institutions. However, several institutions have not yet cooperated with local health centers to be able to fulfill the rights to sustainable healthcare for PMI.

The role of local health center in Implementation of Mental Health is vital and central. It plays the role as a gate keeper that receive reports from both institutions and society regarding stocked PMI, as well as being coordinative either with health services or with related sector in sub-district level, as a first health center to give references to health facilities that are regional general hospitals and psychiatric hospitals to then give treatments to outpatients during recovery phase. The role of local health center in fulfilling rights to healthcare for PMI relies on the activeness of its officials on site in handling stocked PMI cases.

The role of family and society, including the district officials in fulfilling rights to healthcare for PMI is significantly determined by family and society's understanding. Social factor and social power play an important role in implementing the law of banning stocks and fulfilling rights to healthcare for stocked PMI. Social power factor emerges from the influence of PMI's family, local public figures, health center officials and social services workers.

In daily information, people can find out events and actions that can be categorized as violations of the law that cause victims or losses, both in individuals and in society. An interesting impression arises, as if irony has occurred because violations of the law occur in the midst of the process of community development [5]. The government must be able to give affirmation to the community, the law that is made leads to the interests of the community and oriented towards social justice [6]. Indonesia today is faced with a very "unique" problem of law performance regarding the formal truth treated as the most dominant consideration of legal decision embracing reine Rechtslehre Kelsenian's way of thinking. An approach that is still in further discussion through a more holistic alternative paradigm [7]. Law is an important element in the development of politics and it makes the relationship with government policy clearer. Through legislation, the Government determines what it can do and what not to do. Law defined as legislation is a system of norms where the rule of law is arranged in unity within a hierarchical manner. The lower legal norms should not be contradictory to the higher legal norms [8].

The value of usefulness will direct law toward consideration of community needs in a certain period, so that law will have a powerful role in society. The value of usefulness obtained that will be society's consideration is PMI's recovery, expecting them to be the member of society who play their role well, creating security within family and society. For related efforts to realize an effective law system it is necessary to reorganize the legal institution, which is supported by qualified human resources and culture and a growing awareness of the community about law [9].

Closest ones and PMI's family naturally do not want to use stocks, but they are compelled to do it due to PMI's harmful behaviors to themselves, family members, and the environment. PMI who are without supervision and leave the house causes more worries to the family because there are potential harms following them. As for female PMI, the family is concerned about certain misconducts, such as sexual abuse and rape.

All PMI's families visited by the researcher acknowledged the law banning the use of stocks, although their knowledge only covers general information, excluding articles in regulations. Only a few PMI's families who recognize the rights to healthcare for PMI because most of them do not know that PMI have access to healthcare as a process toward recovery. And this knowledge is not equipped with submission to related law. Submission to law regulating stocks use and rights to healthcare is a result of law internalization process caused by social influences affecting cognition of individual in PMI'sfamily - attitude and behaviors [5]. Eventually, legal act that was taken by 9 PMI's families to give rights to healthcare and treatments in Psychiatric Hospitals or outpatient treatments in local health centers using NHI. Legal act taken by 2 PMI's families was not fulfilling PMI's rights to healthcare, they take alternative treatment or in fact take no action and choose to use stocks to this point regardless of social insurance granted by government in form of JKN-KIS. Foundation of his opinion stems from the assumption that in the implementation of law, one aspect not to overlook is the role of people or members of society who are the subject or legal regulations but the implementation of law is determined by attitude, perspectives, and values adopted by the members of society (legal culture). In the regulation banning the use of stocks and fulfilling rights to healthcare for PMI, the role of family and society should not be disregarded in terms of perspective, attitude and values that constitute the legal culture of stocks releasing and fulfilling rights to healthcare.

\section{CONCLUSION}

Policies regulating healthcare for stocked People with Mental Illness (PMI) in Majalengka Regency is oriented toward positive law that is currently in effect as it is written in Law Number 18 Year 2014 regarding Mental Health and Regional Regulation of West Java Province Number 5 Year 2018 regarding Implementation of Mental Health.

Rights to healthcare for PMI can be fulfilled by healthcare as outpatients given by a psychiatrist (mental health doctor) as inpatient treatment is currently unavailable.

The role of local health center is central in fulfilling rights to healthcare for PMI because the local health center plays the role as gate keeper, as well as being coordinative, and serves as the first health center to give treatments and references for outpatients. 
PMI's family's knowledge about law serves as the basis of their decision to unlock stocks and grant PMI with rights to healthcare. This knowledge is influenced by socialization conducted by local health center officials, district officers, and social services workers. The PMI's family's awareness of law regulating the use of stocks is already present, however the legal awareness about fulfilling rights to healthcare for PMI is not yet blossomed due to the lack of understanding the importance of fulfilling rights to healthcare for PMI.

\section{REFERENCES}

[1] Biro Komunikasi dan Pelayanan Masyarakat Kementrian Kesehatan Republik Indonesia, Peran Keluarga Dukung Kesehatan Jiwa Masyarakat, Jakarta, 2016

[2] Health Policy and Management Center Medical School, New Paradigm in Mental Healthcare and its Implications on Public Policies in NHI Era, Yogyakarta: Gadjah Mada University, 2017.

[3] E. Sutrisno, "Implementasi Pengelolaan Sumberdaya Pesisir Berbasis Pengelolaan Wilayah Pesisir Secara Terpadu Untuk Kesejahteraan Nelayan”, Jurnal Dinamika Hukum, vol. 14, no.1, pp. 3, 2014.
[4] E. Sutrisno, "The Study Of River Pollution Related To Domestic Waste In The Perspective Of Community Legal Culture", South East Asia Journal Of Contemporary Business, Economics and Law, vol. 12, pp. 134, 2017.

[5] E. Sutrisno, Rekonstruksi Budaya Hukum Masyarakat Nelayan Untuk Membangun Kesejahteraan Nelayan Studi Kritis Terhadap Pemaknaan Hukum, Yogyakarta: Genta Press, 2013, pp. 97.

[6] E. Sutrisno, "Relations Between Legal Culture and Economic Empowerment among Marginalized Group of Farmers", Journal of Legal, Ethical and Regulatory Issues, vol. 22, issue 3, pp. 223-329, 2019.

[7] E. Sutrisno, "Tracing the Performance of Law in Indonesia (A Perspective of Thomas Kuhn's "Normal Science", Journal of Law, Policy and Globalization, International Institute for Science, Technology \& Education Accelerating Global Knowledge Creation and Sharing, vol. 37, pp. 126, 2015.

[8] E. Sutrisno and I. Jazilah, "The Licensing Policy for Groundwater Extraction and Management for Hospitality Industry in Cities in Developing Countries", Journal Water Policy, IWA Publishing, vol. 21, issue 3, pp. 1-10, 2019.

[9] E. Sutrisno, "The Legal Problem of Using Non Environmentally Friendly Fishing Gear in the Fisher Community of Indonesia," EurAsian Journal of BioSciences, vol. 13, issue 2, pp. 2107, 2019. 